\title{
Analysis of Standards, Certifications and Labels for Bio-based Products in the Context of Sustainable Bioeconomy
}

\author{
Stefania Bracco, Food and Agriculture Organization of the United Nations, Rome, Italy \\ Özgül Calicioglu , Food and Agriculture Organization of the United Nations, Rome, Italy \\ Alessandro Flammini, United Nations Industrial Development Organization (UNIDO), Vienna, Austria \\ Marta Gomez San Juan, Food and Agriculture Organization of the United Nations, Rome, Italy \\ Anne Bogdanski, Food and Agriculture Organization of the United Nations, Rome, Italy
}

\begin{abstract}
Bioeconomy has been proposed as a pathway to sustainable development in many countries. However, the difficulties in defining the bioeconomy boundaries at the national level might necessitate the adoption of a sectoral approach to monitor and evaluate the success of its development. In this resolution, standards, certifications and labelling (SCL) schemes for bioeconomy-related sectors might be an essential source of data. The study evaluates the potential to use SCL schemes as a source for monitoring and evaluating sustainable bioeconomy, by analysing the sustainability aspects (chain-ofcustody, environmental, economic and social themes) considered in selected SCL schemes. A variety of SCL schemes for different stages of the bioeconomy value chains were subjected to analysis on whether they consider internationally agreed aspirational principles and criteria for sustainable bioeconomy. The aspects most frequently mentioned by the requirement lists of the analysed SCL schemes were identified, along with the highlights on the least-frequently mentioned sustainability topics.
\end{abstract}

\section{KEYWORDS}

Bioeconomy, Biomass, Bioproducts, Certifications, Labels, Standards, Sustainability

\section{INTRODUCTION}

Bioeconomy is the utilization of biomass to produce not only food and feed, but also energy, chemicals and materials. Due to its promising potential in addressing global challenges, bioeconomy has been directly or indirectly included in policy agendas worldwide as a way to decouple growth and petroleum dependency (Bracco, Calicioglu, Gomez San Juan, \& Flammini, 2018; and Bracco \& Flammini, 2018). However, bioeconomy is not sustainable per se, especially considering the competition it poses for natural resource inputs for food (Calicioglu, Flammini, Bracco, Bellu, \& Sims, 2019), and other aspects such as whether bioeconomy improves working conditions for the employees. Furthermore, the impact of bioproducts and their value chains are not inclined to territorial boundaries, and they rather globally affect society and ecosystems. Therefore, information on the overall sustainability of the bioproducts is of particular concern for sustainable development.

Data availability can often be an issue in sustainability monitoring frameworks related to bioeconomy. Nevertheless, standard, certification and labelling (SCL) schemes for biomass and 
bioproducts can provide insights on the overall sustainability of bioeconomy at the product level, as they increase information flows throughout the value chain and in the market (FAO, 2003). They help all value chain actors (producers, manufacturers, distributors, traders and consumers) disclose information and choose the right products for their purpose. Over the last years, several SCL schemes have been developed by the private and public sectors (e.g. OK biobased Vinçotte), as well as by international organizations (e.g. Green Gold Label). In the context of bioeconomy, existing SCL schemes prove the bio-based content of a product, intend to demonstrate the extent of its sustainability, or inform on the product end-of-life options (e.g. biodegradability, compostability and disintegration of a product). For instance, the European Union (EU) delegates the evaluation of the sustainability of biofuels entering its market to voluntary schemes approved by the Commission (Bracco, 2015). This EU biofuel regulatory regime introduces a double delegation: the European Commission entrusts the partners of the approved SCL schemes to ensure biofuel sustainability; and the schemes delegate third party auditors to guarantee their behaviour.

SCL schemes send a message to the actors of the value chain and the consumers. This information increases access to market and brand value, confidence, traceability, and facilitates risk management (due diligence system). SCL schemes often help companies comply with national and international legislations, such as the international labour standards set by the International Labour Organization (ILO) or environmental law. Consumers, particularly in developed countries such as the members of the EU, are more and more prepared to buy goods and services which have reduced environmental impacts (European Commission, 2008). For example, consumers are often willing to pay a higher price that is also called "Green Premium" for a more sustainable bio-based product (Carus, Eder, \& Beckmann, 2014; Dammer et al., 2017). Therefore, by increasing market information, the certification of a bioproduct can also enhance the development of its market and favours, for instance, public procurement (Dubois \& Gomez San Juan, 2016; Lynch, Klaassen, \& Broerse, 2017).

Despite the needs in bioeconomy sustainability monitoring and the potential opportunities that SCL schemes offer as a data source, a comprehensive analysis of the current status on how sustainability is addressed in bioeconomy-related SCL schemes is lacking. In this respect, this study aims to assess which sustainability criteria are requested by the existing SCL schemes for bio-based products, in order to determine to what extent the SCL schemes can be used to monitor and evaluate the sustainability of bioeconomy development at the product level.

The study presents certification options for different types of biomass and bioproducts, and analyses the aspects considered by the selected certification schemes, mainly focusing on whether a given certification option considers the chain-of-custody $(\mathrm{CoC})$ and sustainability standards. To this end, in order to outline sustainability criteria, a collation of topics has been identified on the basis of the aspirational principles and criteria for sustainable bioeconomy (summarised in Appendix A), developed and validated by the International Sustainable Bioeconomy Working Group (ISBWG). This working group comprises representatives of governments, research and international organizations, and it has been established by the Food and Agriculture Organization of the United Nations (FAO).

In the scope of this study, the analysed SCLs cover different stages of the value chain of a biobased product, from biomass to biomaterials and final bioproducts entering the market. The study refers to products from the following bioeconomy sectors: agricultural sectors (agriculture, forestry, and fisheries), bio-based construction materials and furniture, pulp and paper, bio-based textiles, biobased chemicals and polymers, bioenergy; and to end-of-life certification. Food and feed are excluded. The selection of certification schemes for biomass, forest products, agricultural commodities, biofuels and biomaterials, prioritises those standards that are not applicable just in one country because the analysis aims to be global in scope. In the context of this work, products of biological origin that are not classified under another listed category are considered "other" bioproducts. For the "other" bioproducts and end-of-life certification schemes, this study also includes a few national SCLs, since there are only a limited number of available initiatives worldwide. A systematic analysis of the SCL schemes for the final products in the mentioned categories is performed, particularly because the compilation under these categories have not been previously undertaken comparatively. 


\section{BACKGROUND: STANDARDS, CERTIFICATIONS AND LABELS FOR BIO-BASED PRODUCTS}

Standards, certifications and labels can be applied to different goods and sectors. This study divides the SCL schemes into the categories according to the intended final product from the biomass: (1) biomass (not related to a particular sector), (2) forest products and agricultural commodities, (3) biofuels and biomaterials (as intermediate products), (4) "other" bioproducts (bioproducts that are not biomass, forest products, agricultural commodities, biofuels and biomaterials); and adds a separate category of (5) end-of-life of a commercialized bioproduct. In this scope, this work excludes certification schemes targeting only food and feed products, and heat/power since extensive literature is available for these sectors. It also excludes certification schemes endorsed by laboratories (mostly in research companies) in the dermatological area that evaluates the safety and effectiveness of cosmetic, pharmaceutical and home care products through clinical studies, because they are targeted only to a very limited set of products. The compendium of standards does not attempt to be exhaustive when it comes to single product groups or environmental labels available at the national level.

Most certifications for biomass and bio-based products refer to national, regional and international standards developed by technical committees organised in standardisation bodies. Therefore, the study presents the main international (International Organisation for Standardisation, ISO), and regional (such as the European Committee for Standardisation, CEN) standards that are often referred to by the certification schemes. These standards and guidelines do not directly certify the products; therefore, they are kept separated from certification schemes considered above. In the EU, the main standards and guidelines specific to bio-based products are EN 16640; EN 16751; EN 16760; EN 16785-1; EN 16785-2; EN 16848 and EN 16935; EN 13432; CEN/TC 411 and CEN/TS 16137:2011. Standards and guidelines adopted internationally are, for instance, the ones developed by the International Organization for Standardization (ISO). ISO develops International Standards but does not issue certificates. Relevant ISO standards for biomass and bioproducts are: ISO 9001:2015; ISO 14001:2015; ISO 20400:2017; ISO 26000:2010 and ISO 13065:2015. Bio-based certification schemes are usually based on highly recognized standards (e.g. EN, ISO or ASTM standards) and rely on third-party certification (European Bioplastics, 2016). They can be made by indicating either the bio-based mass content of the total mass as a percentage of the total mass or the bio-based carbon content as a percentage of the total carbon content or the final material/product. The methodology used to calculate the carbon content is the 14-C or radiocarbon method (EU: EN 16640 or CEN/TS 16137, International: ISO 16620-2, US: ASTM 6866) (European Bioplastics, 2016).

Descriptions and targets analysed on initiatives related to biomass (Table 1), forest products and agricultural commodities (Table 2), biofuels and biomaterials (Table 3), "other" bioproducts (Table 4) and end-of-life options (Table 5) are provided in this section. The SCL schemes analysed are promoted by industries, government, non-governmental organizations or international organizations. The reviewed initiatives are numerous, since certification schemes often target a specific product (e.g. soy, palm oil, sugar, biochar) because they are promoted by roundtables that represent the stakeholders in that particulars industry. Moreover, the SCL schemes can cover different steps of the product value chain (e.g. the whole value chain or just some segments of it).

For biofuels, this study analyses, in particular, the several voluntary schemes for biofuels and bioliquids used in the EU to comply with the sustainability criteria set by the Renewable Energy Directive 2009/28/EC (RED). These schemes are mostly privately run but recognized as valid to demonstrate compliance with the sustainability criteria by the European Commission for a period of five years (European Commission, 2019). The voluntary schemes recognized by the European Commission are marked with an asterisk $(*)$ hereafter. 


\section{ANALYTICAL APPROACH}

In order to define the aspects covered by the analysed SCL initiatives (for biomass, forest products, agricultural commodities, biofuels, biomaterials, "other" bioproducts, and end-of-life of a commercialized bioproduct as described in Background Section), this study has developed four groups of themes, namely, $\mathrm{CoC}$, environmental, economic and social. Consecutively, the schemes were skimmed to perform a spreadsheet-based gap analysis to identify the criteria covered under each of these four groups.

The first theme of topics deals with the $\mathrm{CoC}$ requirements (including mass balance/ segregation measures in manufacturing and logistics, performance, the traceability of the bioproducts and risk assessment and management) and the bio-based carbon and mass contents requirements, while the last three groups examine the economic, environmental and social sustainability of the activities. The rest of the sustainability aspects (i.e. environmental, economic and social) to be assessed by this work have been identified based on the sustainable bioeconomy principles and criteria (P\&C) (Appendix A). The $\mathrm{P} \& \mathrm{C}$ were adapted and interpreted to identify topics that can be relevant for analysing companies' behaviour and covering the economic, environmental and social aspects included in the SCL schemes. For instance (see Table 6), Criterion 1.1. Food security and nutrition are supported matches the social topic Food security and nutrition (food availability, access, utilization and stability, 1a), which was used to examine whether a given SCL scheme addresses this aspect (i.e. in order to evaluate whether SCL can be used to inform bioeconomy development in terms of food security and nutrition).

In some cases, there is no one-to-one correspondence between criteria and topics. For instance, one criterion sometimes matches more than one topic (e.g. topics $4 \mathrm{~b}$ and $4 \mathrm{c}$ both address criterion 4.2). The topics identified do not necessarily cover all aspects of the $P \& C$, but are limited to those issues relevant to SCL initiatives targeting private sector actors. The topics for which the selected initiatives were scanned through are classified according to the themes and associated topics as demonstrated in Figure 1.

Since the ultimate goal of this study is to illustrate which sustainability aspects are most often and least often mentioned in the lists of requirements proposed by the selected certification schemes, the authors define the former as "frequent" topics and the latter as "sporadic". However, the scope of the SCL scheme was taken into account during this practice; if a criterion was out of scope for the scheme, it has not been considered as missing.

Table 1. Descriptions and targets of analysed initiatives on biomass

\begin{tabular}{|l|l|}
\hline Name & Description and target \\
\hline $\begin{array}{l}\text { Better Biomass } \\
\text { NTA8080 }\end{array}$ & $\begin{array}{l}\text { For a) bioenergy not included in the Renewable Energy Directive 2009/28/EC (RED) and } \\
\text { bio-based products or b) RED biomass products* (biofuels or bioliquids). Targets the EU and } \\
\text { includes references to European (EN) standards. Concerns the complete supply chain from } \\
\text { production, processing, transport to end use. }\end{array}$ \\
\hline $\begin{array}{l}\text { Green Gold Label } \\
\text { (GGL) }\end{array}$ & $\begin{array}{l}\text { For biomass in the energy and bio-based sectors (woody agri-residues, waste wood biomass, } \\
\text { and bioliquids): in particular the standards for the chain of custody (GGLS1), agricultural } \\
\text { source criteria (GGLS2) and forest management criteria (GGLS5). Global in scope. }\end{array}$ \\
\hline $\begin{array}{l}\text { REDcert-EU and } \\
\text { REDcert system* }\end{array}$ & $\begin{array}{l}\text { Has been revised and valid in all European Member States and selected third countries (Ukraine } \\
\text { and Belarus). Targets biomass (agricultural raw materials) and refers to the International } \\
\text { Sustainability and Carbon Certification (ISCC-EU) and Biomass Biofuels Sustainability } \\
\text { voluntary scheme (2BSvs) certification schemes. }\end{array}$ \\
\hline
\end{tabular}


Table 2. Descriptions and targets of analysed initiatives on forest products and agricultural commodities

\begin{tabular}{|c|c|}
\hline Name & Description and target \\
\hline $\begin{array}{l}\text { Forest Stewardship } \\
\text { Council (FSC) }\end{array}$ & $\begin{array}{l}\text { The CoC Certification for forest-based materials and products (Version 3-0 active from } \\
\text { 01/04/2017) is analysed in the context of our work. Provides a foundation for forest management } \\
\text { standards and has a global geographic coverage. }\end{array}$ \\
\hline $\begin{array}{l}\text { Programme for the } \\
\text { Endorsement of } \\
\text { Forest Certification } \\
\text { (PEFC) }\end{array}$ & $\begin{array}{l}\text { This work analyses both a) the CoC certification for wood and wood-based materials based } \\
\text { on ISO 9001:2008, ISO 14001:2004 and ISO 14020:2000; and b) the standards for timber } \\
\text { procurement. }\end{array}$ \\
\hline $\begin{array}{l}\text { Sustainable Forestry } \\
\text { Initiative (SFI) }\end{array}$ & $\begin{array}{l}\text { The three SFI standards analysed are: a) SFI 2015-2019 Forest Management Standard; b) SFI } \\
\text { 2015-2019 Fiber Sourcing Standard; c) SFI 2015-2019 CoC Standard. Common principles apply } \\
\text { to the SFI 2015-2019 Forest Management Standard and SFI 2015-2019 Fiber Sourcing Standard. } \\
\text { These SFI principles are supported by additional mandatory requirements. These requirements } \\
\text { include more specific objectives, performance measures and indicators. The SFI 2015-2019 } \\
\text { Forest Management Standard applies to organizations in the United States and Canada. The SFI } \\
\text { 2015-2019 Fiber Sourcing Standard applies to organizations in the United States and Canada that } \\
\text { procure wood domestically or globally. SFI 2015-2019 CoC Standard applies to any organization } \\
\text { globally. }\end{array}$ \\
\hline Bonsucro EU* & $\begin{array}{l}\text { Compliance with Bonsucro requirements plus additional requirements that are needed for EU } \\
\text { RED compliance (in line with the EU Renewable Energy Directive, (RED) 28/2009/EC, similar } \\
\text { provisions exist in the EU Fuel Quality Directive (FQD) 30/2009/EC and amendments included } \\
\text { in Directive 2015/1513). Bonsucro Production Standard and Bonsucro CoC Standard are } \\
\text { analysed together to count for EU RED compliance. }\end{array}$ \\
\hline $\begin{array}{l}\text { Rainforest Alliance } \\
\text { Sustainable } \\
\text { Agriculture } \\
\text { Standard (RA SAS) }\end{array}$ & $\begin{array}{l}\text { Forms the foundation of Rainforest Alliance certification for farms and producer groups involved } \\
\text { in crop and cattle production and are complemented with general Certification Rules and Policies } \\
\text { on Pest Management. For certain countries and topics, additional policies have been developed as } \\
\text { needed. Also includes a Continuous Improvement System which defines a sequential progression } \\
\text { of sustainability performance over a six-year period beginning with the first certification audit. } \\
\text { The Rainforest Alliance as an independent, non-profit organization is also accredited for FSC } \\
\text { auditing and certification. The Rainforest Alliance RA-Cert Division conducts FSC certification } \\
\text { evaluations but it is not separately analysed in this study since the criteria are those of the FSC } \\
\text { certification. }\end{array}$ \\
\hline $\begin{array}{l}\text { Roundtable on } \\
\text { Sustainable Palm } \\
\text { Oil (RSPO-RED)* }\end{array}$ & $\begin{array}{l}\text { The requirements for compliance with the EU Renewable Energy Directive requirements } \\
\text { have been designed to be used in conjunction with the RSPO Principles \& Criteria, the RSPO } \\
\text { Certification System requirements, the RSPO Supply Chain Certification System requirements } \\
\text { and the RSPO Supply Chain Certification Standard. }\end{array}$ \\
\hline $\begin{array}{l}\text { Round Table on } \\
\text { Responsible Soy } \\
\text { (RTRS)* }\end{array}$ & The RTRS EU RED Scheme applies to products derived from soybean. \\
\hline
\end{tabular}

\section{RESULTS AND DISCUSSION}

Table 6 shows the analysis of the certification schemes, according to the criteria they cover for the certification of bio-based products, as well as their end-of-life practices. SCL schemes for biomass, forest products, agricultural commodities, biofuels and biomaterials cover more socio-economic and environmental aspects when compared to the certification schemes for "other" bioproducts and end-oflife. In particular, the certification for bioproducts other than forest products, agricultural commodities and biofuels do not cover socio-economic aspects and focus more on the CoC and bio-based mass content. In fact, this is not a limitation but is due to the scope of the certification schemes at hand. Yet, this fact might be a concern in terms of the overall sustainability of the system. Socio-economic or environmental aspects of a product are out of the scope of some certification schemes also for biobased products. Likewise, since eco-friendly product certification schemes do not necessarily certify the bio-based carbon content, the related topics have been excluded from the evaluation of frequent 
Table 3. Descriptions and targets of analysed initiatives on biofuels and biomaterials

\begin{tabular}{|c|c|}
\hline Name & Description and target \\
\hline $\begin{array}{l}\text { The KZR INIG } \\
\text { System* }\end{array}$ & $\begin{array}{l}\text { System of certification for biofuels and bioliquids related to the RED sustainability criteria } \\
\text { developed by the Oil and Gas Institute in Poland. Analyses the whole chain including } \\
\text { cultivation, processing, transport, conversion, and trade of raw materials cultivated and } \\
\text { harvested, as well as wastes and residues collected, for biofuel and bioliquid production. }\end{array}$ \\
\hline HVO Scheme & $\begin{array}{l}\text { Scheme for the verification of compliance with the RED sustainability criteria for biofuels*: } \\
\text { Nestle Oil leads the system development, for an economic operator in the value chain aimed at } \\
\text { producing HVO-type (hydro-treated vegetable oil) renewable diesel from various raw materials } \\
\text { to comply with the RED requirements. }\end{array}$ \\
\hline $\begin{array}{l}\text { International } \\
\text { Sustainability and } \\
\text { Carbon Certification } \\
\text { (ISCC)* }\end{array}$ & $\begin{array}{l}\text { As a global certification system, covers the entire supply chain and all types of bio-based } \\
\text { feedstocks and renewables. The bio-based products certification scheme specifically targets } \\
\text { the entire supply chain of the products derived from biomass. Here the authors cover the } \\
\text { ISCC certification for biofuels in the context of our study. The ISCC bio-based products } \\
\text { related sections have been analysed separately for bio-based products (Table } 4 \text { ). With regards } \\
\text { to biofuels' certification, the ISCC Document } 202 \text { "Sustainability Requirements" comprises } \\
\text { of six sustainability principles, which have been determined in a multi-stakeholder process. } \\
\text { Principle } 1 \text { covers the legal requirements of Articles } 17(3), 17(4) \text { and } 17(5) \text { of the EU RED and } \\
\text { Articles } 7 \text { b(3), (4) and (5) of the Fuel Quality Directive 2009/30/EC amended through Directive } \\
2015 / 1513 / \text { EC } 2 \text { (FQD), as well as the further requirements on defining the criteria and } \\
\text { geographic ranges of highly biodiverse grassland as set by the Commission Regulation (EU) No } \\
1307 / 2014 \text { of } 8 \text { December } 2014 \text {. ISCC Principles } 2-6 \text { are not based on legal requirements, but } \\
\text { have been developed in multi-stakeholder dialogue and represent best practices. }\end{array}$ \\
\hline $\begin{array}{l}\text { Roundtable on } \\
\text { Sustainable } \\
\text { Biomaterials (RSB)* }\end{array}$ & $\begin{array}{l}\text { The RSB Principles \& Criteria for the Sustainable Production of Biomass, Biofuels and } \\
\text { Biomaterials (RSBSTD-01-001) describe best practices in the production and processing of } \\
\text { biomass, and in the production of biofuels and biomaterials. The standard described herein } \\
\text { specifies requirements for the certification of sustainable operations along the entire supply } \\
\text { chain. }\end{array}$ \\
\hline $\begin{array}{l}\text { The Biomass } \\
\text { Biofuels } \\
\text { Sustainability } \\
\text { voluntary scheme } \\
\text { (2BSvs)* }\end{array}$ & $\begin{array}{l}\text { Founded in } 2010 \text { by a consortium of French biomass and biofuels associations (the "2BS } \\
\text { Consortium"). The scheme was primarily set up to cover the mandatory sustainability } \\
\text { requirements of Directive 2009/28/EC for all feedstocks and biofuel. }\end{array}$ \\
\hline $\begin{array}{l}\text { IBI Biochar } \\
\text { Certification } \\
\text { Program }\end{array}$ & $\begin{array}{l}\text { Voluntary, self-certifying biochar certification programme administered by the International } \\
\text { Biochar Initiative (IBI). The purpose of the programme is to provide biochar manufacturers the } \\
\text { opportunity to certify their biochar(s) by the minimum criteria established in the most recent } \\
\text { version of the 'IBI Standardized Product Definition and Product Testing Guidelines for Biochar } \\
\text { That Is Used in Soil', which serves as the foundation of the IBI Biochar Certification Program. } \\
\text { Currently, the IBI Biochar Certification Program focuses only on implementation in the United } \\
\text { States and Canada. IBI Biochar Certification Program does not certify any other products, } \\
\text { such as a product mixed with biochar, and does not address issues of sustainability, energy or } \\
\text { greenhouse gas (GHG) balance, or life cycle analysis. These IBI Biochar Standards identify } \\
\text { three categories of tests for biochar materials (IBI, 2015): } \\
\text { Test Category A - Basic Utility Properties: measures the most basic properties required to } \\
\text { assess the utility of a biochar material for use in soil; } \\
\text { Test Category B - Toxicant Assessment: biochar made from processed feedstocks must be } \\
\text { tested more frequently than biochar made from unprocessed feedstocks; } \\
\text { Test Category C - Advanced Analysis and Soil Enhancement Properties: biochar may be tested } \\
\text { for advanced analysis and enhancement properties in addition to meeting test requirements for } \\
\text { Test Categories A and B. All tests in Test Category C are optional. Manufacturers may report } \\
\text { on none, one, some or all of the properties. }\end{array}$ \\
\hline
\end{tabular}

topics. Similarly, product end-of-life practices (biodegradability, compostability and disintegration) and sustainable consumption (of bioeconomy goods) do not apply to many certification schemes for biomass, forest products, agricultural commodities and biofuels. On Table 6, "not-applicable" topics 
Table 4. Descriptions and targets of analysed initiatives on "other" bioproducts

\begin{tabular}{|c|c|}
\hline Name & Description and target \\
\hline $\begin{array}{l}\text { Cradle to Cradle } \\
\text { Certified }^{\mathrm{TM}}(\mathrm{C} 2 \mathrm{C})\end{array}$ & $\begin{array}{l}\text { Products Program guides designers and manufacturers through a continual improvement } \\
\text { process (e.g. step-wise improvement or improvement in segments) that looks at a product } \\
\text { through five quality categories - material health, material reutilization, renewable energy and } \\
\text { carbon management, water stewardship, and social fairness. }\end{array}$ \\
\hline $\begin{array}{l}\text { DIN-Geprüft Biobased } \\
\text { (products based } \\
\text { on renewable raw } \\
\text { materials) }\end{array}$ & $\begin{array}{l}\text { Applies to products that are fully or partly manufactured from bio-based raw materials, and in } \\
\text { conjunction with the basic testing standards in alignment with their properties. It contains all } \\
\text { of the requirements for awarding the "DIN-Geprüft biobased" certification mark. }\end{array}$ \\
\hline EU Eco-Label & $\begin{array}{l}\text { Covers a wide range of product groups, from major areas of manufacturing to tourist } \\
\text { accommodation services to assess whether they are environmentally friendly, as claimed. } \\
\text { The specifications depend on the product type, and are mostly based on the best available } \\
\text { techniques. The EU Eco-Label is a voluntary scheme, which means that producers, importers } \\
\text { and retailers can choose to apply for the label for their products. In the context of this study, } \\
\text { the product labelling schemes of the sectors, which could be relevant to bioeconomy (i.e. pulp } \\
\text { and paper, chemicals, textiles, and construction materials and furniture) are analysed. }\end{array}$ \\
\hline Blue Angel & $\begin{array}{l}\text { Guarantees that a product or service meets high standards in terms of environmental, health } \\
\text { and performance characteristics. In the process, these products and services are evaluated } \\
\text { across their entire life cycle. Criteria are developed for each product group that must be } \\
\text { fulfilled by those products and services awarded with the Blue Angel. In order to reflect } \\
\text { technological advances, the Federal Environmental Agency of Germany reviews these criteria } \\
\text { every three to four years. In the context of this study, the product labelling schemes of the } \\
\text { sectors, which could be relevant to bioeconomy (i.e. pulp and paper, chemicals, textiles, and } \\
\text { construction materials and furniture) are analysed. }\end{array}$ \\
\hline $\begin{array}{l}\text { International } \\
\text { Sustainability and } \\
\text { Carbon Certification } \\
\text { (ISCC) for bio-based } \\
\text { products }\end{array}$ & $\begin{array}{l}\text { Emphasizes the mass balance of the products, which implicitly gives an idea on the bio- } \\
\text { based content. Since this scheme is very comprehensive, only the sections related to bio- } \\
\text { based products have been analysed separately as bio-based product scheme. The normative } \\
\text { requirements of bio-based product certification were listed as: ISCC PLUS } 204 \text { on "Options } \\
\text { to add further chain of custody requirements", ISCC PLUS } 205 \text { "Consumables", ISCC } \\
\text { PLUS } 207 \text { "Risk Management", ISCC PLUS } 254 \text { "Integrity Program", ISCC PLUS } 260 \\
\text { "Waste feedstocks and renewable feedstocks of non-biological origin", ISCC PLUS } 203 \\
\text { "Requirements for Traceability", and "ISCC PLUS } 20501 \text { GHG Emission Requirements". }\end{array}$ \\
\hline $\begin{array}{l}\text { NEN bio-based } \\
\text { content }\end{array}$ & $\begin{array}{l}\text { Based on the European standard EN 16785-1 that enables independent assessment of claims } \\
\text { on the bio-based content of products (basic materials, intermediate and finished products). }\end{array}$ \\
\hline OK biobased Vinçotte & $\begin{array}{l}\text { For all products that are (partially) manufactured from bioplastics and materials of natural } \\
\text { origin. On a basis of the determined percentage of renewable raw materials (\% bio-based), the } \\
\text { products are certified under four main categories: one-star-bio-based }(20-40 \%) \text {, two-star-bio- } \\
\text { based }(40-60 \%) \text {, three-star-bio-based }(60-80 \%) \text { or four-star-bio-based }(>80 \%) \text {. }\end{array}$ \\
\hline $\begin{array}{l}\text { USDA Biobased } \\
\text { Product Certification }\end{array}$ & $\begin{array}{l}\text { Managed by the U.S. Department of Agriculture (USDA) under the USDA Voluntary } \\
\text { Labelling Initiative, to help consumers in identify bio-based products and packages in } \\
\text { the general marketplace. Around } 2,700 \text { of the } 14,200 \text { products of the USDA BioPreferred } \\
\text { Programme display an USDA Certified Bio-based Product label. It applies to all bio-based } \\
\text { products and certifies on the basis of percent bio-based carbon, and percent biomass content of } \\
\text { the final product. The certification also includes the reporting of the grain and oilseed inputs } \\
\text { used in bio-based product manufacturing. }\end{array}$ \\
\hline
\end{tabular}

(out of the scope of the scheme) are indicated with grey cells, and excluded from the calculation of the percentages. Therefore, the percentages given in the last column of Table 6 is derived from the number of ticks in each row divided by the total number of relevant schemes only (i.e. for which the sustainability aspects applies, excluding the grey cells).

In the context of the study, the relevant sectors in labelling schemes (i.e. Eco-Label and Blue Angel) are analysed and lumped into one column. The sectoral coverage of sustainability criteria; 
Table 5. Descriptions and targets of analysed initiatives on end-of-life

\begin{tabular}{|c|c|}
\hline Name & Description and target \\
\hline $\begin{array}{l}\text { DIN-Geprüft } \\
\text { biodegradable in soil } \\
\text { (manufactured items) }\end{array}$ & $\begin{array}{l}\text { Applies to (end) products made of materials or intermediates which are biodegradable in } \\
\text { soil, and in connection with the testing specifications, contains all requirements on issuing } \\
\text { the conformity mark "DIN-Geprüft Biodegradable in soil" and certificates for materials } \\
\text { and intermediates. Reports on compliance with the threshold chemical values in a provided } \\
\text { list, ultimate biodegradability disintegration in soil, effect on soil and eco-toxicity of both } \\
\text { the materials used for manufacturing and the end product are sought for certification. If } \\
\text { the product to be certified falls under a certain category, the regional and/or international } \\
\text { standards for those categories apply for the product. }\end{array}$ \\
\hline $\begin{array}{l}\text { DIN-Geprüft } \\
\text { Industrial compostable } \\
\text { products }\end{array}$ & $\begin{array}{l}\text { Applies to (end) products made of compostable materials or inter-mediates, and, in connection } \\
\text { with the testing foundations. Products, intermediates and materials can be certified and/or } \\
\text { registered according to the following certification standards: DIN EN 13432, DIN EN 14995, } \\
\text { ISO 17088, ISO } 18606 \text { and AS } 4736 \text {. Laboratory testing must be performed according to the } \\
\text { stipulations in the standards named above according to the following standards or test methods: } \\
\text { DIN EN ISO 14851, DIN EN ISO 14852, DIN EN ISO 14855-1, DIN EN ISO 14855-2, } \\
\text { ASTM D 5338, ISO 16929, DIN EN 14045, DIN EN 14046, DIN EN ISO 10634, ASTM E } \\
\text { 1676, AS 4454, OECD 208. Basic requirements are biodegradability, disintegration, compost } \\
\text { quality (eco-toxicity), chemical characteristics (whether they are from the positive list). }\end{array}$ \\
\hline OK compost Vinçotte & $\begin{array}{l}\text { Certifies the claims on compostability of products, materials and intermediates. The } \\
\text { testing must be completed in accordance with set testing standards. Basic requirements are } \\
\text { biodegradability, disintegration, compost quality (eco-toxicity), chemical characteristics } \\
\text { (whether they are from the positive list). Although developed for Belgium, this scheme is } \\
\text { widely used in the E.U. }\end{array}$ \\
\hline $\begin{array}{l}\text { OK biodegradable } \\
\text { Vinçotte }\end{array}$ & $\begin{array}{l}\text { Certifies the claims on biodegradability of products, materials and intermediates in soil, water } \\
\text { and marine environments. Two versions exist for home and industrial compostability. The main } \\
\text { difference is in the conditions under which the product can be composted. The testing must be } \\
\text { completed in accordance with set testing standards. Basic requirements are biodegradability, } \\
\text { disintegration, environmental safety (eco-toxicity), chemical characteristics (whether they are } \\
\text { from the positive list). Depending on the biodegradation environment (water, soil or marine), } \\
\text { the biodegradability test applied changes. }\end{array}$ \\
\hline REDcert-DE & $\begin{array}{l}\text { The waste product checklist and the associated supply chain checklist for the sustainable } \\
\text { collection and handling, and transportation have been taken into account for this section. } \\
\text { (including the checklist for the inspection of operations that supply waste and residual } \\
\text { materials, and the checklist for the inspection of interfaces and suppliers). }\end{array}$ \\
\hline Seedling logo & $\begin{array}{l}\text { The Seedling logo is a registered trademark owned by European bioplastics. Proves that a } \\
\text { product is certified industrially compostable according to the European standard EN } 13432 . \\
\text { The Seedling may be featured only if the respective compostable product has been formally } \\
\text { certified. The certification process is carried out by the independent certifiers DIN CERTCO } \\
\text { Germany) and Vinçotte (Belgium) according to the certification scheme "Products made of } \\
\text { compostable materials". The certification scheme is based on the European norm EN } 13432 \text {. }\end{array}$ \\
\hline
\end{tabular}

however, is also presented in Appendix B, Table 8, where the coverage of topics in the EU Eco-Label and Blue Angel certifications are shown with details for the chemicals, pulp and paper, construction and textile sectors (Appendix B).

\section{Topics Related to the Theme of Chain-Of-Custody}

The "sustainability characteristics" can include information about the type and origin of the raw material, the certification scheme of the material and relevant complements (ISCC, 2016b). A mass balance system allows the physical mixing of masses while keeping the account for different "sustainability characteristics" separate. The mixture of feedstocks can happen at the first gathering point, in the warehouse, during transport, in processing or logistic installation, or at a conversion site. Most of the schemes for biomass, forest products, agricultural commodities, biofuels and biomaterials 
Figure 1. The topics for which the selected initiatives were scanned through are classified according to the themes (chain-ofcustody, economic, environmental and social) and associated topics

\section{CHAIN OF CUSTODY}

\author{
Bio-based carbon content \\ Bio-based mass content \\ Mass balance / segregation \\ Chain-of-Custody performance \\ 6c. Traceability (transparent sharing of information,) \\ 6d. Risk assessment and management, monitoring and \\ accountability
}

\section{ENVIRONMENTAL}

1b. Sustainable intensification of biomass production (e.g. sustainable management of land, soil, forests and marine environments)

2a. Biodiversity conservation

2b. Sustainable use of biodiversity (e.g. restriction on GMO use) 2c. Climate change adaptation and mitigation (e.g. GHG emissions accounting and/or mitigation)

2d. Management and maintenance of water quality and quantity 2e. Avoidance of degradation of land, soil, forests and marine degradation

2f. Preservation of land, soil, forests and marine environments (including HCV areas; land with high carbon stock; ILUC; wetlands) 4c. Ecosystem resilience (e.g. integrated pest management and control; avoidance of hazardous chemicals in production) 5a. Resource efficiency (e.g. energy efficiency, renewable energy and cascading)

5b. Waste prevention and re-use

5c. Food loss and waste

5d. Sustainable product end-of-life practices (biodegradability; compostability and disintegration)

\section{ECONOMIC}

3a. Financial and economic viability (safe and healthy business environment, e.g. continual improvement)

3b. Inclusive economic growth (e.8. profitability, increase in workers' income, job creation)

$3 d$. Economic resilience in rural and urban areas (e.g. resilience to food prices fluctuation; economic stability)

7b. Knowledge generation and innovation

8a. Sustainable trade and market practices (e.g. avoid illegal trade)

9a. Sustainable production (e.g. coherence in the production of food and non-food goods and management of natural resources) 9b. Sustainable consumption (of bioeconomy goods)

\section{SOCIAL} 1a. Food security and nutrition (food availability, access,
utilization and stability)

1c. Land rights and rights to other natural resources (including land tenure)

1d. Food safety, disease prevention and human health

3c. Social inclusion (e.g. poor, women, youth, minorities, indigenous groups)

4a. Health and sustainability of communities

$4 \mathrm{~b}$. Social resilience of biomass producers and rural communities 4d. Labour conditions

6a. Compliance with relevant national regulations and laws

6b. Consultation process and stakeholder engagement (e.g. FPIC)

7 a. Existing relevant knowledge, proven sound technologies and good practices

10a. Complaint/Grievance mechanisms

have a requirement concerning a mass balance system. This fact is also because a suitable mass balance system guarantees that the requirements of the RED are met (art. 18). Other CoC requirements refer in particular to transparency, traceability (6c) and risk assessment and management, as well as monitoring and accountability (6d).

In a few cases, the mass balance indicators report the percentage of wood certified in the final product; for instance, the FSC and the PEFC offers different types of certification (e.g. FSC 100\%; FSC Mix x\% / FSC Mix Credit; FSC Recycled x\% / FSC Recycled Credit; FSC Controlled Wood or PEFC Controlled Sources). Similarly, the SFI CoC standard certifies forest content.

Certification schemes for "other" bioproducts mostly include the bio-based carbon content and the bio-based mass content of the final product. However, except for IBI and RED cert-DE, none of the schemes for biomass, forest products and agricultural commodities, biofuels and biomaterials, or end-of-life include bio-based carbon/mass contents.

\section{Topics Related to the Theme of Environmental Sustainability}

The environmental criteria are more frequent in the SCL analysed, because the RED sustainability requirements (article 17) cover aspects such as GHG emission savings; conservation of biodiversity (primary forest and other wood land, protected areas, highly biodiverse grassland); conservation of 
carbon stocks (wetlands, continuously forested areas, forested areas with 10-30\% canopy cover); conservation of peatlands. In particular, sustainable intensification of biomass production (1b); biodiversity conservation (2a); sustainable use of biodiversity (2b) and preservation of land, soil, forests and marine environments (2f) are frequent topics mentioned by the vast majority of the certification schemes for biomass, forest and agricultural commodities, biofuels and biomaterials. Climate Change adaptation and mitigation (2c) is a target of all the biomass and biofuels certification schemes analysed but is not included in some forest-related certification. The "other" bioproducts certification schemes do not focus on the environmental topics. However, schemes for "eco-friendly" products, such as Eco-Label and Blue Angel, which include bioeconomy sectors (e.g. wood), consider environmental topics, such as Climate Change adaptation and mitigation, Management and maintenance of water quality and quantity (2d), avoidance of degradation of land, soil, forests and marine environments (2e), ecosystem resilience (4c) and waste prevention and re-use (5b). Only one certification (ISCC energy) covers the food loss and waste (5c) since it requires that all people on the farm/plantation have access to clean food storage areas as basic service. The sustainable product end-of-life (biodegradability; compostability and disintegration) topic (5d) is frequent, especially in the certification of the end-of-life options for the products. In addition, management and maintenance of water quality and quantity, avoidance of degradation of land, soil, forests and marine degradation, and ecosystem resilience (especially of hazardous chemicals release) are required for the end-of-life certification schemes.

\section{Topics Related to the Theme of Economic Sustainability}

The economic aspects identified from the sustainable bioeconomy $\mathrm{P} \& \mathrm{C}$ are often not prioritized by SCL schemes. In particular, economic topics are sporadic in certification schemes for "other" bioproducts and end-of-life. Schemes for biomass, forest products and agricultural commodities, and biofuels and biomaterials often report on aspects related to financial and economic viability (3a), such as the adoption of continual improvement procedure and/or health and safety procedure (e.g. the occupational safety and health (OHAS) CoC management system), or to sustainable production (9a). Aspects related to inclusive economic growth (3c); economic resilience in rural and urban areas (3d); and sustainable trade and market practices (8a) are instead considered by six SCLs only. Even more sporadic is knowledge generation and innovation (7b), which is considered by five certification schemes only. Since the SCL initiatives analysed refer to the production side of bioproducts, none of the certifications refers to the sustainable consumption of bioeconomy goods (9a).

\section{Topics Related to the Theme of Social Sustainability}

Social topics are often mentioned as a means to avoid conflicts with local stakeholders and thus to reduce risks. For this reason, most SCLs envisage complaint and/or grievance mechanisms (10a). A very important factor to avoid conflicts is the recognition of land rights and rights to other natural resources (1c), which is frequent in the SCLs. Equally important is the consultation process and stakeholder engagement (6b), which; however, is not mentioned by the majority of the certification schemes analysed. The most frequent social criterion is compliance with relevant national regulations and laws (6a). Most certification schemes also have requirements concerning labour conditions (4d), often referring to the ILO standards. Health and sustainability of communities (4a) is another topic often considered, as it includes local communities' well-being or prosperity, safeguarding the livelihoods of the communities and families, rural and social development. Social inclusion of poor, women, youth, minorities, indigenous groups (3c) and social resilience of biomass producers and rural communities (4b) are mentioned only by one-fifth of the analysed SCLs. Social resilience of biomass producers and rural communities includes respect to human rights and a decent standard of living (Rainforest Alliance, 2017), for workers and their families. Food security and nutrition (1a), food safety, disease prevention and human health (1d) and existing relevant knowledge, proven sound technologies and good practices (7a) are not considered by most of the analysed certification schemes. 
The "other" bioproducts topics do not include social aspects. However, schemes for eco-friendly products and ISSC include health and sustainability of communities (4a), labour conditions (4d), compliance with relevant national regulations and laws (6a), consultation process and stakeholder engagement (6b). The end-of-life certification schemes very often cover the social topics of health and sustainability of communities (4a), compliance with relevant national regulations and laws (6a), and complaint/grievance mechanisms (10a).

\section{ANALYSIS AND SUMMARY OF THE MAIN RESULTS}

Figure 1 presents the frequency of topics relevant to the FAO $\mathrm{P} \& \mathrm{C}$, which are measured by bioeconomy value chain actors to different extents in order to comply with existing certification schemes. The percent frequencies of $\mathrm{P} \& \mathrm{C}$ topics identified in each SCL theme are calculated from the results of the stocktaking and gap analysis performed, detailed results of which are presented on Table 6. The topics are classified by stages of a bioproduct value chain (i.e., biomass, forest products and agricultural commodities, biofuels and biomaterials, "other" bioproducts, and end-of-life practices) to highlight differences among these broad categories.

One of the reasons behind more frequent coverage of some criteria might be their relative importance to the developer or the stakeholders of the SCL at hand. For example, since greenhouse gas reduction targets are a priority for the EU, requirements related to climate change adaptation and mitigation are observed more frequently in the SCL schemes that have the geographic coverage of the EU. The topics encountered more frequently in relevant SCL schemes indicate data or information that are available (and are expected to be increasingly more available) to monitor the sustainability of the bioeconomy sectors.

The GGL, RA Sustainable Agriculture Standard, ISCC Energy and RSB EU RED Standard have encompassing requirements that target important socio-economic aspects that are often neglected by the other SCL schemes. Therefore, these schemes can be used as the best examples covering important sporadic environmental and socio-economic aspects, such as inclusive economic growth and food security. Among the themes of topics selected for this study, those related to the environmental sustainability are more commonly covered by SCLs (in particular climate change adaptation and mitigation, management and maintenance of water quality and quantity and waste prevention and re-use). One reason for the stronger adoption of environmental topics compared to the other groups is the compliance with the environmental requirements mandated by the EU RED.

The bioproduct certification schemes, which only certify the biomass/carbon contents, have less emphasis on the environmental performance of the final products (Table 6). However, eco-friendly product certification schemes such as Eco-Label and Blue Angel, which do not specifically target bioproducts but can be applied to them, have a stronger focus on the environmental performance of the products. In this respect, the bioproduct certification schemes are quite limited in nature in terms of sustainability certification. The eco-friendly certification schemes for the products within bioeconomy sectors, as well as in the schemes related to biomass and biofuels production provide insights on how the copes of the bioproducts certification schemes can be improved the future. Figure 2 shows that socio-economic aspects are covered less by analysed schemes. Most certification schemes limit their social standards to workers' conditions and compliance with relevant national regulations and laws. A reason to adopt social topics is their potential in the avoidance of conflicts with local stakeholders and the reduction of risks. Therefore, several certification schemes include a complaint and/or grievance mechanisms; the recognition of land rights and rights to other natural resources and consultation process and stakeholder engagement.

However, the other socio-economic topics have little emphasis on the SCL schemes analysed. They are often unpractical to measure; in particular, when the rights and livelihoods of surrounding communities are involved. For instance, food security, food safety, local knowledge, inclusive economic growth (e.g. profitability, increase in workers' income, job creation), economic resilience (e.g. 
Table 6. Analysed certification schemes, their geographical coverages and included topics

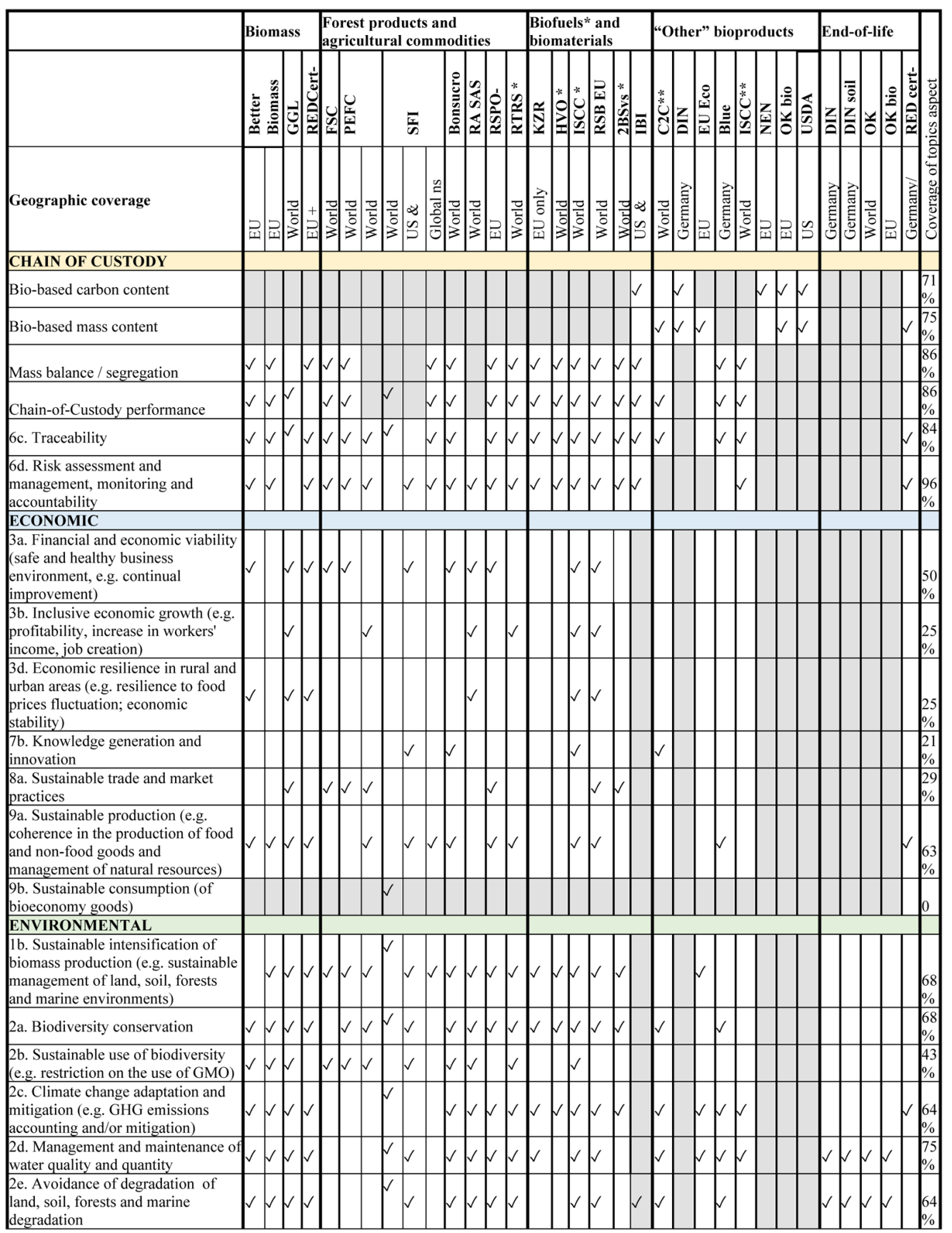




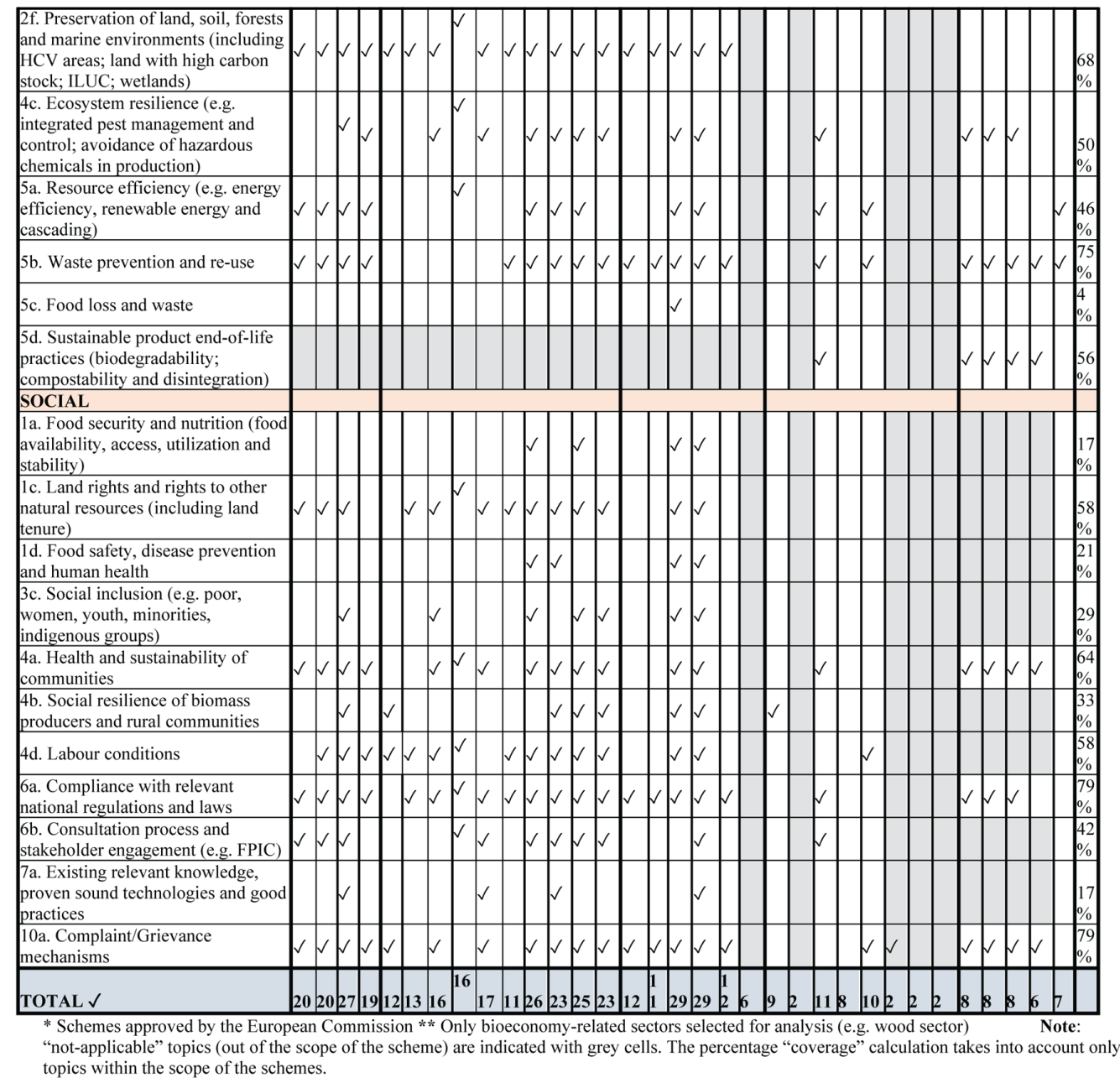

resilience to food prices fluctuation; economic stability) and sustainable trade and market practices are largely ignored by most certification schemes. This is particularly true for SCL schemes applicable to bioproducts other than biomass, forest products and biofuels ("other" bioproducts) and to end-of-life.

The missing coverage of topics in an SCL scheme often reflects the difficulty in their measurement. In such cases, indications on the level of adoption of bioeconomy good practices can provide a more practical and cost-effective approach to inform the contribution to sustainable development. When topics are not easily measurable, some SCL schemes suggest an alternative measurement based on the adoption of good practices. For instance, in order to address the economic resilience in rural and urban areas, the REDCert-EU requires to discuss with customers the best timing for crop deliveries to ensure good prices and to maintain quality (REDcert, 2017). GGL requires instead a systematic collection of data on production systems and yields, costs and prices (GGL, 2017), which allows the monitoring of economic resilience. Regarding the inclusive economic growth topic, associated good practices can include: the creation of local employment (GGL, 2017; PEFC, 2012); the improvement of the socio-economic status of local stakeholders impacted by the operations and/or the creation of year-round and/or long-term jobs (RSB, 2016); fair opportunities for employment 
Figure 2. Frequency of P\&C topics identified in each SCL theme (i.e. (A) chain-of-custody, (B) environmental, (C) economic, and (D) social). The percentages of SCL schemes mentioning a particular topic are provided for each bioeconomy value chain element (i.e. biomass, forest products and agricultural commodities, biofuels* and biomaterials, "other" bioproducts and their end-of-life) are presented with bars. Each interval between dashed lines correspond to $50 \%$. Note: The calculation takes into account only topics within the scope of the schemes. The numbers refer to the topics derived from the P\&C.

A)

B)

C)

D)
Chain of custody: Bio-based carbon content Bio-based mass content Mass balance / segregation Chain-of-Custody performance 6c. Traceability 6d. Risk assessment and management, monitoring and.

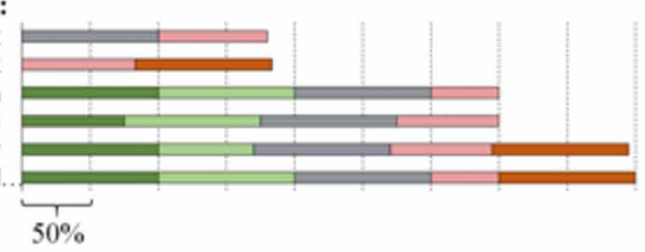

Economic:

3a. Financial and economic viability

3 b. Inclusive economic growth 3d. Economic resilience in rural and urban areas $7 \mathrm{~b}$. Knowledge generation and innovation 8a. Sustainable trade and market practices 9a. Sustainable production $9 b$. Sustainable consumption (of bioeconomy goods)

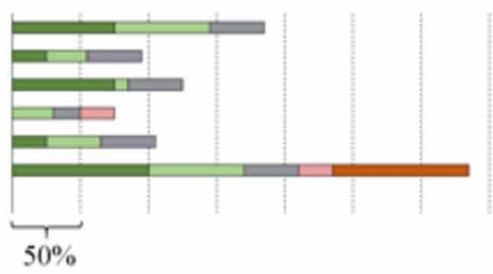

Environmental:

Ib. Sustainable intensification of biomass production 2a. Biodiversity conservation 2b. Sustainable use of biodiversity 2c. Climate Change adaptation and mitigation 2d. Management and maintenance of water quality and quantity 2e. Avoidance of degradation of land, soil, forests and marine. 2f. Preservation of land, soil, forests and marine environments 4c. Ecosystem resilience 5a. Resource efficiency $5 b$. Waste prevention and re-use $5 \mathrm{c}$. Food loss and waste 5d. Sustainable product end-of life practices

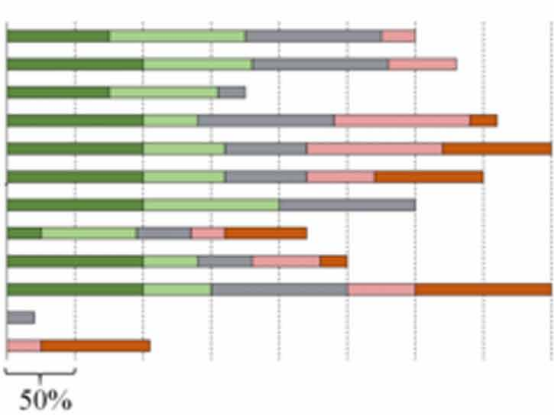

Social: la. Food security and nutrition Ic. Land rights and rights to other natural resources Id. Food safety, disease prevention and human health $3 \mathrm{c}$. Social inclusion 4a. Health and sustainability of communities $4 \mathrm{~b}$. Social resilience of biomass producers and rural communities 4d. Labour conditions 6a. Compliance with relevant national regulations and laws 6b. Consultation process and stakeholder engagement 7a. Existing relevant knowledge, proven sound technologies. 10a. Complaint/Grievance mechanisms

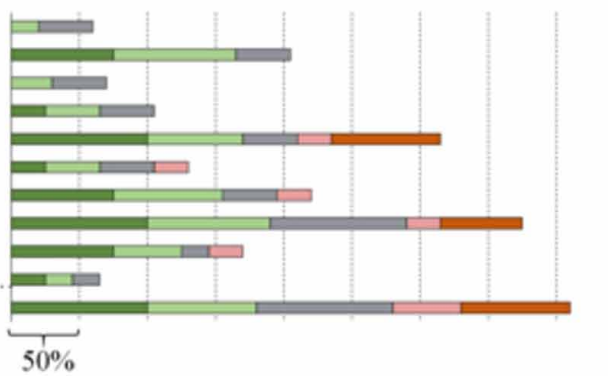

a Biomass $\square$ Forest products and agricultural commodities

$\square$ Biofuels $^{*}$ and bio-materials $\square$ Other bio-products $\quad$ End of life

and provision of goods and services to the local population (RTRS, 2010). An additional point to highlight is the scarce attention given by the SCL schemes to the topics derived from Principle 7 (Sustainable bioeconomy should make good use of existing relevant knowledge and proven sound technologies and good practices, and, where appropriate, promote research and innovation). In fact, existing relevant knowledge, proven sound technologies and good practices, as well as knowledge generation and innovation are mentioned only by $16-21 \%$ of the schemes analysed. These schemes in particular focus on: training and education (SFI, 2015); effective and focused research, development and extension expertise (Bonsucro, n.d.); technical knowledge and training (ISCC, 2016a); traditional 
knowledge and skills (GGL, 2017); recognition and respect of indigenous peoples' rights and traditional forest-related knowledge (SFI, 2015); improving farming practices, management systems, and farmer knowledge (Rainforest Alliance, 2017); ensuring that local customs, languages, practices and indigenous knowledge are respected and utilised (RSB, 2016).

Similarly, the topics related to food security, food safety and food waste (1a, 1d, and 5c) are mentioned just by respectively $20 \%, 21 \%$ and $4 \%$ of the analysed schemes. This implies that usually the schemes for biomass and bio-commodities do not recognize the impact of deploying bioeconomy on food-related issues. On the other hand, these aspects have been included, for instance, by RSB by assessing risks to food security in the region and locality and mitigating any negative impacts that result from the operations, and by enhancing the local food security of the directly affected stakeholders in food insecure regions (RSB, 2016).

The bioproduct certification schemes currently monitor compliance with just two criteria (percentage of bio-based carbon or mass content). Sustainability certification for individual product schemes (i.e. Blue Angel, Eco-Label etc.), especially for the products entirely included in bioeconomy since they are entirely bio-based (such as wood products), could serve as a reference for potential improvement of bio-based product certification schemes to evaluate their environmental performances (e.g. utilization of toxic chemicals during manufacturing process).

Another common approach to assess the performance of bio-based products is to build upon the experience and comprehensive assessments of biofuel certification schemes (the latter often takes into account a wider range of sustainability aspect including food security).

Finally, one other important point regarding end-of-life certification schemes is that they could be adhered into other certification schemes, as every product eventually has a suitable end-of-life option. For example, a bio-based product does not necessarily have to be compostable, and vice versa. In fact, organic carbon content (which can be either fossil-based or bio-based) does not necessarily imply that all of the carbon content had been derived from biomass. For instance, fossil-based plastics contain organic carbon, yet, not necessarily biomass-derived carbon. Therefore, end-of-life sustainability indicators can be applied to all product categories.

The decision on whether a product would end up in a landfill or in sustainable alternative end-of-life strategies (i.e. re-use, recycle, or composting) is very much dependent on the consumer behaviour. Therefore, education of the consumers and clear labelling is key for public participation in the implementation of the intended end-of-life strategies for a product. Only after when proper disposal methods are adopted, the end-of-life schemes can provide practical information related to the fate of bioproducts. In this respect, increasing the public awareness would be as important as the certification of the product, and in fact, there are set standards for this purpose, such as ISO 14020 series. These sets of standards would also be useful references and requirements to foster proper disposal of the compostable and/or biodegradable products.

Considering the gaps identified in the relevant information provided by the SCL schemes, additional indicators might be necessary to monitor and evaluate the sustainability of bioeconomy development at the product level. Therefore, these schemes can serve as a last resort in case data are not available for a more comprehensive list of indicators. In this regard, the recent FAO report (Bracco, Tani, Calicioglu, Gomez San Juan, \& Bogdanski, 2019) provides insight on the selection of relevant indicators to monitor and evaluate the sustainability of bioeconomy. The FAO suggested methodology reviews existing monitoring approaches to identify two comprehensive lists already available indicators, one at product level and one at territorial level, and discusses the gaps and weaknesses emerged in the reviewed literature with regard to social, economic and environmental impact categories of the bioeconomy, and associated data availability. The FAO study identifies solutions and a possible way forward to help countries and practitioners in their bioeconomy monitoring and evaluation efforts: a stepwise approach to monitoring the bioeconomy sustainability, including the selection of relevant indicators, by means of a flexible, participatory approach build on indicators and data that are already available and countries/stakeholders may already report on. In 
fact, in developing a bioeconomy monitoring system is important to strengthen the already existing standards, requirements and indicators, as those used by the SCL schemes reviewed in this manuscript, to avoid putting additional burdens on the stakeholders.

\section{CONCLUSION}

This study classified and analysed bioeconomy-related SCL schemes according to stages of a bioproduct value chain (i.e., biomass, forest products and agricultural commodities, biofuels and biomaterials, "other" bioproducts, and end-of-life practices) to investigate whether these schemes can be used as a data source to evaluate bioeconomy sustainability at the product level.

The analysis of existing standards and certification options provides an indication of the adoption of sustainability standards, and therefore suggests which topics are already commonly measured by value chain actors and which ones require additional efforts to be monitored by SCL. Our results show that SCL schemes can be used to inform product sustainability in terms of environmental aspects. However, socio-economic standards should go hand in hand with $\mathrm{CoC}$ and bio-based mass content indicators to guarantee the sustainable growth of a dynamic bioeconomy.

\section{ACKNOWLEDGMENT}

The authors are thankful to Olivier Dubois, FAO Senior Natural Resources Officer, and Almona Tani, Sapienza University of Rome, for proving technical inputs to the paper. The study was funded in the framework of FAO project GCP/GLO/724/GER "Towards Sustainable Bioeconomy Guidelines (SBG)" supported by the German Federal Ministry of Food and Agriculture (BMEL). The views expressed in this paper are those of the authors and do not necessarily reflect the views or policies of their employer organizations. 


\section{REFERENCES}

Bonsucro. (n.d.). Assessment of Bonsucro EU.

Bracco, S. (2015). Effectiveness of EU biofuels sustainability criteria in the context of land acquisitions in Africa. Renewable \& Sustainable Energy Reviews, 50, 130-143. doi:10.1016/j.rser.2015.05.006

Bracco, S., Calicioglu, O., Juan, M. G. S., \& Flammini, A. (2018). Assessing the contribution of bioeconomy to the total economy: A review of national frameworks. Sustainability (Switzerland), 10(6). doi:10.3390/su10061698

Bracco, S., \& Flammini, A. (2018). Assessing the contribution of bioeconomy to countrys' economy. Rome: FAO.

Bracco, S., Tani, A., Calicioglu, O., Gomez San Juan, M., \& Bogdanski, A. (2019). Indicators to monitor and evaluate the sustainability of bioeconomy development. Overview and a Proposed Way Forward. Rome: FAO.

Calicioglu, O., Flammini, A., Bracco, S., Bellu, L., \& Sims, R. (2019). The Future Challenges of Food and Agriculture: An Integrated Analysis of Trends and Solutions. Sustainability (Switzerland), 11(222). doi:10.3390/ su11010222

Carus, M., Eder, A., \& Beckmann, J. (2014). GreenPremium Prices Along the Value Chain of Biobased Products. Industrial Biotechnology (New Rochelle, N.Y.), 10(2), 83-88. doi:10.1089/ind.2014.1512

Dammer, L., Carus, M., Iffland, K., Piotrowski, S., Sarmento, L., Chinthapalli, R., \& Raschka, A. (2017). Current situation and trends of the bio-based industries in Europe. Pilot Study for BBI JU.

Dubois, O., \& Gomez San Juan, M. (2016). How sustainability is addressed in official bioeconomy strategies at international, national, and regional leveles - An overview. Food and Agriculture Organization of United Nations.

European Bioplastics. (2016). Accountability is key. In Environmental Communications Guide. Academic Press. doi:10.1177/019263659107553913

European Commission. (2008). The Sustainable Consumption and Production and Sustainable Industrial Policy Action Plan. EU Law and Publications. Retrieved from http://eur-lex.europa.eu/

European Commission. (2019). Voluntary schemes. Retrieved from https:/ec.europa.eu/energy/en/topics/ renewable-energy/biofuels/voluntary-schemes

FAO. (2003). Environmental and Social Standards, Certification and Labelling for Cash Crops. Raw Materials, Tropical and Horticultural Products Service (ESCR). Commodities and Trade Division. Retrieved from http:// www.fao.org/docrep/006/Y5136E/y5136e07.htm

GGL. (2017). Green Gold Label Program GGLS2 - Agricultural Source Criteria.

IBI. (2015). Standardized Product Definition and Product Testing Guidelines for Biochar That Is Used in Soil. In International Biochar Initiative. . 22

ISCC. (2016a, June 23). (Manuscript submitted for publication). Assessment of International Sustainability \& Carbon Certification system (ISCC). Version as.

ISCC. (2016b). ISCC PLUS 204-01 Mass Balance Requirements. 10.1016/B978-0-08-037944-9.50009-1

Lynch, D. H. J., Klaassen, P., \& Broerse, J. E. W. (2017). Unraveling Dutch citizens' perceptions on the bio-based economy: The case of bioplastics, bio-jetfuels and small-scale bio-refineries. Industrial Crops and Products, 106, 130-137. doi:10.1016/j.indcrop.2016.10.035

PEFC. (2012). Sustainable Timber: a Guide To Procurement for the Public Sector.

Rainforest Alliance. (2017). Sustainable Agriculture Standard For farms and producer groups involved in crop and cattle production. Retrieved from https://www.rainforest-alliance.org/business/sas/wp-content/ uploads/2017/11/03_rainforest-alliance-sustainable-agriculture-standard_en.pdf

REDcert. (2017). Scheme principles for the production of biomass, biofuels and bioliquids.

RSB. (2016). RSB Principles \& Criteria. Retrieved from http://rsb.org/the-rsb-standard/standard-documents/ eu-red/ 
RTRS. (2010). RTRS Standard for Responsible Soy Production. Retrieved from http://www.responsiblesoy.org/ index.php?option=com_docman\&task=doc_download\&gid=290\&Itemid=19\&lang=en

SFI. (2015). SFI 2015-2019 standards and rules. 


\title{
APPENDIX A. CRITERION TABLE
}

\section{Table 7. FAO principles and criteria for sustainable bioeconomy}

\author{
Principle 1. Sustainable bioeconomy development should support food security and nutrition at all levels \\ Criterion 1.1. Food security and nutrition are supported \\ Criterion 1.2. Sustainable intensification of biomass production is promoted \\ Criterion 1.3. Adequate land rights and rights to other natural resources are guaranteed \\ Criterion 1.4. Food safety, disease prevention and human health is ensured
}

Principle 2. Sustainable bioeconomy should ensure that natural resources are conserved, protected and enhanced Criterion 2.1. Biodiversity conservation is ensured

Criterion 2.2. Climate change mitigation and adaptation are pursued

Criterion 2.3. Water quality and quantity are maintained, and, in as much as possible enhanced

Criterion 2.4. The degradation of land, soil, forests and marine environments is prevented, stopped or reversed

\section{Principle 3. Sustainable bioeconomy should support competitive and inclusive economic growth}

Criterion 3.1. Economic development is fostered

Criterion 3.2. Inclusive economic growth is strengthened

Criterion 3.3. Resilience of the rural and urban economy is enhanced

Principle 4. Sustainable bioeconomy should make communities healthier, more sustainable, and harness social and ecosystem resilience

Criterion 4.1. The sustainability of urban centres should be enhanced

Criterion 4.2. Resilience of biomass producers, rural communities and ecosystems is developed and/or strengthened

Principle 5. Sustainable bioeconomy should rely on improved efficiency in the use of resources and biomass Criterion 5.1. Resource efficiency, waste prevention and waste re-use along the whole bioeconomy value chain is improved

Criterion 5.2. Food loss and waste is minimized and, when unavoidable, its biomass is reused or recycled

Principle 6. Responsible and effective governance mechanisms should underpin sustainable bioeconomy

Criterion 6.1. Policies, regulations and institutional set up relevant to bioeconomy sectors are adequately harmonized Criterion 6.2. Inclusive consultation processes and engagement of all relevant sectors of society are adequate and based on transparent sharing of information

Criterion 6.3. Appropriate risk assessment and management, monitoring and accountability systems are put in place and implemented

Principle 7. Sustainable bioeconomy should make good use of existing relevant knowledge and proven sound technologies and good practices, and, where appropriate, promote research and innovation

Criterion 7.1. Existing knowledge is adequately valued and proven sound technologies are fostered Criterion 7.2. Knowledge generation and innovation are promoted

Principle 8. Sustainable bioeconomy should use and promote sustainable trade and market practices

Criterion 8.1. Local economies should not be hampered but rather harnessed by the trade of raw and processed biomass, and related technologies

Principle 9. Sustainable bioeconomy should address societal needs and encourage sustainable consumption Criterion 9.1. Consumption patterns of bioeconomy goods match sustainable supply levels of biomass goods Criterion 9.2. Demand- and supply-side market mechanisms and policy coherence between supply and demand of food and non-food goods are enhanced

Principle 10. Sustainable bioeconomy should promote cooperation, collaboration and sharing between interested and concerned stakeholders in all relevant domains and at all relevant levels

Criterion 10.1. Cooperation, collaboration and sharing of resources, skills and technologies are enhanced when and where appropriate 


\section{APPENDIX B. TABLE 8}

\section{Table 8. Bioproduct certification schemes related to bioeconomy}

\begin{tabular}{|c|c|c|c|c|c|c|c|c|c|c|c|c|c|c|}
\hline & \multicolumn{14}{|c|}{ “Other" bioproducts } \\
\hline & \multirow[b]{3}{*}{ પ્ડ } & \multirow{3}{*}{ 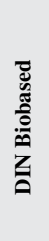 } & \multirow{2}{*}{\multicolumn{4}{|c|}{$\frac{\text { EU }}{\text { Eco label }}$}} & \multirow{2}{*}{\multicolumn{4}{|c|}{ Blue Angel }} & \multirow[b]{3}{*}{$\underset{0}{0}$} & \multirow[b]{3}{*}{ 空 } & \multirow{3}{*}{ 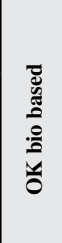 } & \multirow{3}{*}{ 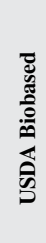 } \\
\hline & & & & & & & & & & & & & & \\
\hline & & & 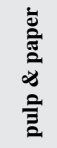 & 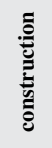 & ঙ를 & 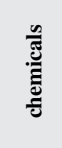 & 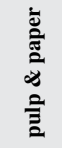 & 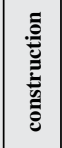 & 产 & 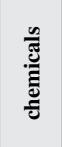 & & & & \\
\hline Geographic coverage & 플 & 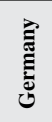 & P & & & & 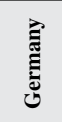 & & & & 플 & 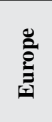 & P & $\tilde{s}$ \\
\hline \multicolumn{15}{|l|}{ CHAIN OF CUSTODY } \\
\hline Bio-based carbon content & & $\checkmark$ & & & & & & & & & & $\checkmark$ & $\checkmark$ & $\checkmark$ \\
\hline Bio-based mass content & $\checkmark$ & $d$ & $d$ & $\checkmark$ & $\checkmark$ & $\checkmark$ & $\checkmark$ & $\checkmark$ & $\checkmark$ & & & & $\checkmark$ & $\checkmark$ \\
\hline Mass balance / segregation & & & & & & & $\checkmark$ & $\checkmark$ & & & $\checkmark$ & & & \\
\hline Chain-of-Custody performance & $\checkmark$ & & & & & & $\checkmark$ & $\checkmark$ & & & $\checkmark$ & & & \\
\hline 6c. Traceability & $\checkmark$ & & & & & & & $\checkmark$ & & & $\checkmark$ & & & \\
\hline $\begin{array}{l}\text { 6d. Risk assessment and management, monitoring } \\
\text { and accountability }\end{array}$ & & & & & & & & & & & $\checkmark$ & & & \\
\hline \multicolumn{15}{|l|}{ ECONOMIC } \\
\hline \multicolumn{15}{|l|}{$\begin{array}{l}\text { 3a. Financial and economic viability (safe and } \\
\text { healthy business environment, e.g. continual } \\
\text { improvement) }\end{array}$} \\
\hline \multicolumn{15}{|l|}{$\begin{array}{l}\text { 3b. Inclusive economic growth (e.g. profitability, } \\
\text { increase in workers' income, job creation) }\end{array}$} \\
\hline \multicolumn{15}{|l|}{$\begin{array}{l}\text { 3d. Economic resilience in rural and urban areas } \\
\text { (e.g. resilience to food prices fluctuation; economic } \\
\text { stability) }\end{array}$} \\
\hline 7b. Knowledge generation and innovation & $\checkmark$ & & & & & & & & & & & & & \\
\hline \multicolumn{15}{|l|}{ 8a. Sustainable trade and market practices } \\
\hline $\begin{array}{l}\text { 9a. Sustainable production (e.g. coherence in } \\
\text { the production of food and non-food goods and } \\
\text { management of natural resources) }\end{array}$ & & & & & $\checkmark$ & & $\checkmark$ & $\checkmark$ & $\checkmark$ & & & & & \\
\hline \multicolumn{15}{|l|}{ 9b. Sustainable consumption (of bioeconomy goods) } \\
\hline \multicolumn{15}{|l|}{ ENVIRONMENTAL } \\
\hline $\begin{array}{l}\text { 1b. Sustainable intensification of biomass } \\
\text { production (e.g. sustainable management of land, } \\
\text { soil, forests and marine environments) }\end{array}$ & & & $\checkmark$ & $\checkmark$ & & & & & & & & & & \\
\hline 2a. Biodiversity conservation & $\checkmark$ & & & & $\checkmark$ & & $\checkmark$ & 1 & $\checkmark$ & $\checkmark$ & & & & \\
\hline \multicolumn{15}{|l|}{$\begin{array}{l}\text { 2b. Sustainable use of biodiversity (e.g. restriction } \\
\text { on the use of GMO) }\end{array}$} \\
\hline $\begin{array}{l}\text { 2c. Climate change adaptation and mitigation (e.g. } \\
\text { GHG emissions accounting and/or mitigation) }\end{array}$ & $\checkmark$ & & $\checkmark$ & $\checkmark$ & $\checkmark$ & $\checkmark$ & $\checkmark$ & $\checkmark$ & $\checkmark$ & $\checkmark$ & $\checkmark$ & & & \\
\hline $\begin{array}{l}\text { 2d. Management and maintenance of water quality } \\
\text { and quantity }\end{array}$ & $\checkmark$ & & $\checkmark$ & $\checkmark$ & $\checkmark$ & $\checkmark$ & $\checkmark$ & $\checkmark$ & $\checkmark$ & $\checkmark$ & $\checkmark$ & & & \\
\hline $\begin{array}{l}\text { 2e. Avoidance of degradation of land, soil, forests } \\
\text { and marine degradation }\end{array}$ & $\checkmark$ & & & & $\checkmark$ & $\checkmark$ & $\checkmark$ & $\checkmark$ & $\checkmark$ & $\checkmark$ & & & & \\
\hline \multicolumn{15}{|l|}{$\begin{array}{l}\text { 2f. Preservation of land, soil, forests and marine } \\
\text { environments (including HCV areas; land with high } \\
\text { carbon stock; ILUC; wetlands) }\end{array}$} \\
\hline $\begin{array}{l}\text { 4c. Ecosystem resilience (e.g. integrated pest } \\
\text { management and control; avoidance of hazardous } \\
\text { chemicals in production) }\end{array}$ & & & $\checkmark$ & $\checkmark$ & & $\checkmark$ & & & & & & & & \\
\hline
\end{tabular}


Table 8. Continued

\begin{tabular}{|c|c|c|c|c|c|c|c|c|c|c|c|c|c|c|}
\hline & \multicolumn{14}{|c|}{ "Other" bioproducts } \\
\hline & \multirow[b]{3}{*}{ ปั } & \multirow[b]{3}{*}{ 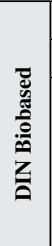 } & \multirow{2}{*}{\multicolumn{4}{|c|}{$\frac{\text { EU }}{\text { Eco label }}$}} & \multirow{2}{*}{\multicolumn{4}{|c|}{ Blue Angel }} & \multirow[b]{3}{*}{$\underbrace{}_{\mathscr{U}}$} & \multirow[b]{3}{*}{ Z } & \multirow[b]{3}{*}{ 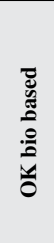 } & \multirow{3}{*}{ 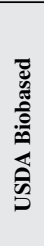 } \\
\hline & & & & & & & & & & & & & & \\
\hline & & & 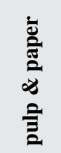 & 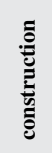 & 䇃 & 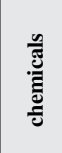 & 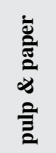 & 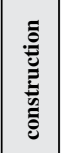 & 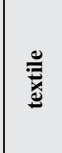 & 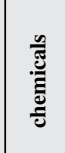 & & & & \\
\hline Geographic coverage & 풀 & 胥 & 空 & & & & 胥 & & & & 훌 & 莺 & ? & $\stackrel{n}{s}$ \\
\hline $\begin{array}{l}\text { 5a. Resource efficiency (e.g. energy efficiency, } \\
\text { renewable energy and cascading) }\end{array}$ & & & $\checkmark$ & $\checkmark$ & & $\checkmark$ & & & & & $\checkmark$ & & & \\
\hline 5b. Waste prevention and re-use & & & $\checkmark$ & 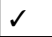 & & $\checkmark$ & & & & & $\checkmark$ & & & \\
\hline \multicolumn{15}{|l|}{ 5c. Food loss and waste } \\
\hline $\begin{array}{l}\text { 5d. Sustainable product end-of-life practices } \\
\text { (biodegradability; compostability and disintegration) }\end{array}$ & & & & & & $\checkmark$ & & $\checkmark$ & & $\checkmark$ & & & & \\
\hline \multicolumn{15}{|l|}{ SOCIAL } \\
\hline \multicolumn{15}{|l|}{$\begin{array}{l}\text { 1a. Food security and nutrition (food availability, } \\
\text { access, utilization and stability) }\end{array}$} \\
\hline \multicolumn{15}{|l|}{$\begin{array}{l}\text { 1c. Land rights and rights to other natural resources } \\
\text { (including land tenure) }\end{array}$} \\
\hline \multicolumn{15}{|l|}{$\begin{array}{l}\text { 1d. Food safety, disease prevention and human } \\
\text { health }\end{array}$} \\
\hline \multicolumn{15}{|l|}{$\begin{array}{l}\text { 3c. Social inclusion (e.g. poor, women, youth, } \\
\text { minorities, indigenous groups) }\end{array}$} \\
\hline 4a. Health and sustainability of communities & & & $\checkmark$ & 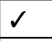 & $\checkmark$ & 4 & & $\checkmark$ & $\checkmark$ & & & & & \\
\hline \multicolumn{15}{|l|}{$\begin{array}{l}\text { 4b. Social resilience of biomass producers and rural } \\
\text { communities }\end{array}$} \\
\hline 4d. Labour conditions & & & & & & & & & & & 2 & & & \\
\hline $\begin{array}{l}\text { 6a. Compliance with relevant national regulations } \\
\text { and laws }\end{array}$ & & & $\checkmark$ & $\checkmark$ & $\checkmark$ & $\checkmark$ & & $\checkmark$ & $\checkmark$ & & & & & \\
\hline $\begin{array}{l}\text { 6b. Consultation process and stakeholder } \\
\text { engagement (e.g. Free, Prior and Informed Consent } \\
\text { - FPIC) }\end{array}$ & & & & $\checkmark$ & $\checkmark$ & $\checkmark$ & & $\checkmark$ & $\checkmark$ & & & & & \\
\hline \multicolumn{15}{|l|}{$\begin{array}{l}\text { 7a. Existing relevant knowledge, proven sound } \\
\text { technologies and good practices }\end{array}$} \\
\hline 10a. Complaint/Grievance mechanisms & & & & & & & & & & & $\checkmark$ & $\checkmark$ & & \\
\hline
\end{tabular}


Stefania Bracco received her PhD in Economics from the University of Siena in 2015. In 2015 she started her collaboration with the Food and Agriculture Organization of the United Nations (FAO), working as consultant on projects and publications about the introduction of sustainable technologies in the agrifood sector and the development of sustainable bioeconomy. Since 2019, she works as Research Facilitator at the University of Gastronomic Sciences, Italy, where she is exploring new, cutting-edge research directions at the frontiers of food and environment-related disciplines.

Özgül Çalıcıoğlu is an Environmental Engineer by training, holding a PhD from the Pennsylvania State University, MS and BS from the Middle East Technical University, and a BA in Management from the Peoples' Friendship University of Russia. She has knowledge and experience related to environmental sustainability, water-energy-food nexus, waste and biomass valorization, environmental biotechnology, bioenergy, and bioeconomy.

Alessandro Flammini is Project Coordinator within the Department of Environment of the United Nations Industrial Development Organization (UNIDO) in Vienna, Austria. Before joining UNIDO in 2018, he was Natural Resources Officer with the Climate, Energy and Environment Department and with the Investment Centre of the Food and Agriculture Organization of the United Nations (FAO), where he worked since 2007. Until 2015, he also worked as independent consultant for UNDP, the European Commission, REEEP, Stanford University, as well as for other public and private companies. Alessandro holds a master's degree in industrial engineering from the University of Bologna, a post-grad master in management of energy resources, and a PhD in environmental sciences from the Vienna University of Technology.

Marta Gomez San Juan is an Agricultural and Biosystems Engineer and Sustainable Bioeconomy Expert in the Climate and Environment Division for the Food and Agriculture Organization of the United Nations.

Anne Bogdanski is a Natural Resources Officer and Project Coordinator of the "Sustainable Bioeconomy Guidelines." She works for the Climate and Environment Division for the Food and Agriculture Organization of the United Nations. 